\title{
PREPARING TEACHERS TO TEACH THE LANGUAGE OF HISTORY
}

Stephanie Garrone-Shufran

Merrimack College

"Language is not a garden tool for acting on inanimate objects but a medium for swaying minds and changing opinions, for rousing passions or allaying them." Samuel Wineburg ${ }^{1}$

According to Robert Bain, history teachers "misunderstand and underestimate the comprehension challenges their students face" in interpreting the varied types of historical texts present in secondary classrooms, while devoting little time to actually teaching them how to engage with these texts. ${ }^{2}$ History teachers' perception of their identities as content area specialists may inhibit the incorporation of language instruction into their teaching practice. ${ }^{3}$ The responsibility for teaching language is seen as belonging solely to the previous year's teachers or the faculty of the English department. ${ }^{4}$ This belief persists despite the move toward a more distributed responsibility for literacy instruction illustrated in the Common Core Standards. ${ }^{5}$ Educational linguists

1 Samuel Wineburg, "On the Reading of Historical Texts: Notes on the Breach Between School and Academy," American Educational Research Journal 28, no. 3 (Fall 1991): 519.

2 Robert B. Bain, "Using Disciplinary Literacy to Develop Coherence in History Teacher Education: The Clinical Rounds Project," The History Teacher 45, no. 4 (August 2012): 516.

3 Christianna Alger, "Engaging Student Teachers' Hearts and Minds in the Struggle to Address (Il)literacy in Content Area Classrooms," Journal of Adolescent and Adult Literacy 50, no. 8 (May 2007): 620.

4 Bain, "Using Disciplinary Literacy," 517.

5 George C. Bunch, Amanda Kibler, and Susan Pimentel, "Realizing Opportunities for English Learners in the Common Core English Language (c) 2020 Garrone-Shufran. Free to copy and share for education and scholarship under a Creative Commons Attribution NonCommercial-NoDerivatives 4.0 License. 
suggest that content teachers, who are experts in their discipline, should view their students as apprentices who require training in all disciplinary practices, including language use and literacy skills. ${ }^{6}$

If history teachers will be responsible for the teaching of the language of history, then they will require training in how to do so. This training in the literacy practices of history needs to become an integral part of the preparation of preservice history teachers. ${ }^{7}$ This article uses case studies to describe the experiences of two aspiring history teachers as they considered how to teach the language of history, and it calls for concerted efforts among language/literacy experts, history educators who specialize in content methods, and historians.

\section{Disciplinary Language}

Preparing teachers of history to incorporate instruction in the language of history into their teaching practice is challenging. History teachers, both pre-service and in-service, are not aware of either how language functions to create meaning in texts or how language proficiency may inhibit access to the content taught in school. These challenges are not unique to preparing history teachers but apply to teacher preparation across the grade spans and disciplines. Since American schools no longer incorporate a systematic study of the English language in the K-12 curriculum, students enter post-secondary education with little foundational knowledge about the functions and features of language. ${ }^{8}$

Arts and Disciplinary Literacy Standards," paper presented at the Understanding Language Conference, Stanford, CA, January 2012.

6 Zhihui Fang and Mary Schleppegrell, Reading in Secondary Content Areas: A Language-Based Pedagogy (Ann Arbor, MI: University of Michigan Press, 2008), 9.

7 Bain, "Using Disciplinary Literacy," 521.

8 Lily Wong Fillmore and Catherine E. Snow, "What Teachers Need to Know about Language," (Center for Applied Linguistics, Washington, D.C., 2000), 30. 
Additionally, teachers in the United States tend to come from middle class, native English speaking homes; their educational experiences were never limited by their language proficiency, and their exposure to academic language in their homes accelerated their ability to use and understand the language of school. ${ }^{9}$

When students are learning history, they are being introduced to a new disciplinary language. The language of the history classroom is used to convey ideas about time, cause and effect, the interaction of present and past, and the relationships among people and their contexts. ${ }^{10}$ Schleppegrell, Achugar, and Oteíza identified language features used to create these meanings in history texts. ${ }^{11}$ By analyzing the action verbs, as well as identifying the agents and the receivers of the actions, a reader can determine what events took place, who was involved in them, and what sorts of power dynamics were at play. Connectors, conjunctions, and temporal prepositional phrases are used to organize the text, setting up sequential or causal relationships.

Historians regard texts as parts of an argument, and as such, all texts are expected to be read critically to evaluate the argument's validity. ${ }^{12}$ Evaluating the argument(s) of the text is accomplished through the processes of sourcing, contextualizing,

9 Alger, "Engaging Student Teachers' Hearts and Minds in the Struggle to Address (Il)literacy in Content Area Classrooms," 621.

10 Suzanne Eggins, Peter Wignell, and J.R. Martin, "The Discourse of History: Distancing the Recoverable Past" in Register Analysis: Theory and Practice, ed. M. Ghadessy (London: Pinter, 1993), quoted in Mary Schleppegrell, The Language of Schooling: A Functional Linguistics Perspective (Mahwah, NJ: Lawrence Erlbaum, 2004), 125.

11 Mary J. Schleppegrell, Mariana Achugar, and Teresa Oteíza, "The Grammar of History: Enhancing Content-Based Instruction through a Functional Focus on Language," TESOL Quarterly 38, no. 1 (Spring 2004): 87.

12 Cynthia Shanahan, Timothy Shanahan, and Cynthia Misischia, "Analysis of Expert Readers in Three Disciplines: History, Mathematics, and Chemistry," Journal of Literacy Research 43, no. 4 (2011): 419. 
and corroborating. ${ }^{13}$ Sourcing involves evaluating the author's perspective and the evidence presented by the author. In contextualizing, historians situate texts as products of their time; the prevailing theories and controversies in the field at that time are also considered as the text is read. Corroborating texts requires that the reader compares evidence from multiple texts and considers the similarities and differences found. In order to successfully "think historically," students must recognize the features of language that create these intended meanings and use discipline-specific ways of interpreting these texts. In considering the points of view included in a text, locating the verbs that indicate saying, thinking, or feeling and analyzing who are the "sayers," "thinkers," or "feelers" provides information on the opinions expressed and whose opinions these are. ${ }^{14}$ Further examination of the messages included with these verbs allows a reader to compare the views and opinions expressed and to determine the multiple viewpoints presented on an event, issue, or theory. ${ }^{15}$

\section{Training in Identifying the Language to Teach}

As a doctoral student, I was asked to take charge of the design and implementation of a training module for preparing preservice teachers in a secondary education program to identify and teach the language of their disciplines. In these two-hour workshops, teacher candidates were taught a process for identifying the features of academic language present in their content area lessons and taught to name specifically in their lesson plans how they would teach the identified features to students. Due to the low numbers of teacher candidates seeking secondary education degrees, the workshops were designed to be delivered to teacher candidates in history, English, math, and the sciences at the

13 Wineburg, "Historical Texts," 510.

14 Schleppegrell, Achugar, and Oteíza, "The Grammar of History," 87.

15 Ibid. 
same time. The workshops were conducted with small groups of teacher candidates so that they could receive individualized attention from the instructor.

Teacher candidates were instructed to bring to the training session a lesson plan which they had previously planned and taught. I modeled the process for identifying the language demands of their lessons using a sample lesson plan. First, we classified each instance in which students were asked to use or understand language in their lesson plans as a listening, speaking, reading, and/or writing demand. After determining the two most important language demands in the lesson, we named the language functions (such as explain, describe, define, and compare) that best described the tasks. Teacher candidates then decided what language features at the word, sentence, and discourselevel needed to be used in completing those tasks. ${ }^{16}$ Word-level features were categorized into two types: general academic words used across content areas and technical words used in a specific discipline. To describe sentence-level structures, teacher candidates engaged in a brainstorm to think about some of the features that are important to writing a correct sentence. Typical responses included verb forms or tenses, nouns, article use, commas, and periods. Discourse-level structures were defined as the amount and quality of language as well as coherence. The example provided was the typical paragraph structure taught to students: a topic sentence, three sentences that support the topic, and a concluding sentence. Finally, to reinforce the idea that teacher candidates were responsible for teaching these language features to students, they were shown both how to create specific language objectives naming these required features and how to explicitly describe how they would teach the features of language they identified in the lesson procedure section of their lesson plan.

16 WIDA, "2012 Amplification of the English Language Development Standards," https://wida.wisc.edu/resources/2012-english-languagedevelopment-standards 
While the training was not discipline-specific, teacher candidates practiced identifying features of academic language in lesson plans they had previously created; therefore, the history teacher candidates were engaging with language specific to teaching and learning in history classrooms.

To collect data on the impact of the training, I sought participants for a study on teacher candidates' identification and instruction of language features in various disciplines. While I did not set out to explore the impact of the training on history teachers specifically, four of the eight participants in the sample were aspiring history teachers. The teacher candidates consented to being observed teaching one lesson at their placement site and being interviewed about the planning and teaching of that lesson. They also submitted the lesson plan and related materials. The lesson planning materials, the implementations of the lessons, and the teacher candidates' reflections in the interviews were brought together to describe what features of the language of history they identified and how that language was taught to students during the lesson. Watching those four teacher candidates teach their lessons and then reflecting with them on their planning and teaching process confirmed for me the importance of teaching the language of history and provided me with insight on the challenges they faced in teaching that language.

Jill was a junior beginning her second of three required fieldwork experiences before she would begin her practicum. Hunter was a senior completing his third and final pre-practicum fieldwork experience. These case studies were chosen because they met two criteria. First, these teacher candidates reported planning their lessons on their own. One of the other history participants was not included because he admitted that he taught a lesson planned entirely by his supervising practitioner. The second criterion was that the teacher candidate taught a lesson in which the language of history was required for understanding or producing texts. The fourth history teacher candidate did teach 
vocabulary words, but his lesson did not require that students understand or produce texts. The two case studies included in this article illustrate the important role that language plays in "doing" history and the difficulties encountered by the teacher candidates as they attempted to identify and incorporate the language of history in their lesson plans.

\section{Jill: Analyzing World War I Poetry}

Jill taught a lesson on identifying the tone and message of World War I poems. Her placement classroom was at a large suburban high school where over a third of the student population were classified as First Language Not English (FLNE). Jill reported receiving no help from her supervising practitioner; he told her to create a lesson on World War I poetry but offered no further guidance in planning the lesson. She planned for students to work in small groups to read and answer questions about one World War I poem and then share their answers with the whole class. Although there were different sets of questions for each poem, all groups were expected to name the tone of the poem, whether it was pro-war or anti-war, and what point of view the poem was told from. Other questions asked students to determine what message readers were meant to take away from the poem and whether that message was valid and reliable based on the author's point of view.

Jill began her implementation of the lesson plan by showing the students a painting, then reading one poem with the students and asking them the types of questions that they would later answer in their groups:

So what do you think the poem is trying to say or the painting trying to say or the two of them together? These are two totally separate artists....So remember these are all points of view coming from different people in the war. So you'll see as you read later on in class they're not just soldiers. They're people in families and people that had different positions in 
war so keep that in mind. Keep point of view in mind when you're reading the poems.

She did not present the terms validity or reliability in this discussion or at any time during the lesson. The word valid appeared on one of the question sheets: "Given the poet's reputation for his feelings towards the war, do you think this poem is a valid representation of how most other people felt about the war?" Other questions hinted at the ideas of validity and reliability, asking students to evaluate whether a poem's message was "an accurate description of Americans' feelings" or whether the point of view expressed in a poem affected the audience's understanding.

In her reflection on the lesson, she said that students had difficulty determining if the poem was a "valid source." She recounted discussing with one student whether or not a poem written by doctor would be regarded as a valid source and how she wanted the student to understand that a doctor, as a respected member of society, would have been believed by others whether or not he was being honest. In reporting this conversation with the student, she cited the student's lack of understanding of how doctors are viewed in society as the root cause for his confusion. She did not seem to connect the student's difficulty in understanding the language, the use of the terms valid and reliable in this context, to the ability to appropriately answer the questions she had posed.

\section{Hunter: Responding to the Attack on Fort Sumter}

In Hunter's lesson, eleventh-grade students listened to a lecture on the events leading up to the attack on Fort Sumter. Then they were asked to write an executive memorandum in which they assumed the role of Abraham Lincoln and explained to the Cabinet the action that would be taken in response to the attack. Hunter struggled to identify any specific features of academic language to be used in these activities. He named 
the language they needed to use "persuasive writing" and he described persuasive writing as "words or phrases that indicate their opinion on the subject." Hunter admitted that he did not know what to identify as academic language. "You saw my ellipses, my dot, dot, dot. Even in my own head, like, 'I don't know what I'm doing here."'

Early in his fieldwork placement, Hunter asked his supervising practitioner what she knew about academic language and found that it "was not as much her wheelhouse. Not really any support on that." Conversely, he said that his university supervisor, a doctoral candidate with whom I had previously collaborated on research related to teacher candidates' development of knowledge about language, was "a lot more in tune with academic language." Hunter's supervisor had provided him with detailed feedback on how to incorporate specific features of language into his lesson plan, asking for specific sentence stems or vocabulary words students should use to persuade. In the end, Hunter did not incorporate his supervisor's suggestions into his lesson plan, because, as he explained, there was no accountability.

After the lecture, Hunter described the persuasive writing activity to students: "You're going to take the position of the Cabinet member that I'm going to give you, and you are going to write [a] memo as if you are President Lincoln saying what action you're going to take." Hunter then presented two different sample memos. The first he showed on a Power Point slide. Using this memo from Franklin Delano Roosevelt, Hunter pointed out that a memo has "important things like where is it coming from, the date, the word memorandum, who's it going towards, and then just specifically what we're talking about and, of course, a nice signature at the bottom." Then he wrote an example of a memo on the whiteboard. It was addressed to himself from "everyone" and it reminded him to move on to the activity because he was running out of time.

When Hunter assessed the memos that the students created, 
he discovered that overall the groups had included the necessary elements; he attributed students' success to looking at the sample memo in the Power Point and also the fact that students had experience writing letters and emails, which contain some of the same elements as a memo. Evaluating the writing that the students had produced during the lesson helped Hunter to explain during his interview what he meant by "persuasive writing" in this context. "So persuasive writing in their memos - they're having to use evidence." He provided examples from the student work he had collected to demonstrate what he meant by using evidence to be persuasive: "Here's the example: 'Advice came to me by way of Mr. Chase, Secretary of the Treasury, who argued that' and then they did quote 'Fort Sumter should in my judgment be reinforced.' And then another one: 'I agree with Mr. Smith when he says, 'believing Fort Sumter can not be successfully defended, I agree its evacuation is a necessity."

The groups who were not as successful in their persuasive writing chose to paraphrase. According to Hunter, "That would probably necessitate a discussion to say that there are better ways. If you actually use someone's actual words, that's more powerful than paraphrasing their words." Hunter wanted students to use direct quotations and integrate them into their writing using a particular format, but he seemed unable to specifically name those features prior to teaching the lesson. Instead he focused on teaching them the structural elements of memos. Reflecting on the student work he collected and talking about what the good examples looked like provided him with an opportunity to dig deeper and think about the features of language that he believed made up "persuasive writing" in this instance.

\section{Incorporating the Language of History into Teaching Practice}

Jill and Hunter both engaged students in activities that required the understanding and use of the language of history. 
Students were not being asked to recall and restate facts but instead interact with their peers to complete targeted reading and writing tasks that involved historical texts. The language demands of these two lessons did illustrate the importance of sourcing, contextualizing, and corroboration in doing history. Jill's analysis of World War I poetry asked students to evaluate sources and, when groups discussed the different poems, they would discover whether evidence to support claims was present across multiple sources. Hunter's memo writing activity asked students to place themselves in a specific historical context and to consider the arguments made in that time and place by the historical figures involved.

However, their experiences also illustrate the challenges that history teachers face when asked to teach the language of history. While Jill required students to engage with primary sources-a painting and poems from the time period-she provided students with little guidance on how to interpret the texts. In order for students to determine what she referred to as "reliability" and "validity" of the poems, the students would need to know what those terms mean and how they should be applied in the context. As she admitted, students were not sure what they were being asked to determine and so were not necessarily successful in their analysis. In addition, her lesson did not clearly focus on uses of language that were discipline-specific. While analyzing multiple sources is valued in history, Jill's activity on poetry did not necessarily reflect the way in which a historian might conduct this sort of analysis. The terminology she used is one aspect that illustrates this issue. Her use of the terms validity and reliability, which are more related to the scientific disciplines, seemed out of place in a history lesson. While she included the word viewpoint in some questions, she did not focus on using this or other terms that would have been more appropriate choices for the discipline, such as source or evidence. Also, the analysis of poetry that the students engaged in looked very similar to an English lesson. 
Her choice of questions about the poems did not engage students clearly in historical thinking, instead focusing on concepts such as tone, more indicative of a literary study. Her lesson would have benefitted from a more direct focus on analyzing specific features of texts, such as analyzing who the "sayers," "thinkers," or "feelers" of each text were and what messages they were conveying. ${ }^{17}$ Conducting analyses in this way might have helped the students make clearer evaluations about the authors of the works and their points of view.

Hunter made a similar choice in terms of language. Although he did teach language to students, the feature he chose to teach was not specifically a feature of the language of history. Hunter spent quite a bit of time on the structure of memos, but he did not teach any features of what he believed to be the necessary "persuasive" language to students for use in the memos: the integration of direct quotations into the written text. The ability to integrate evidence from sources in writing is an important skill in the discipline of history. Hunter clearly wanted a specific type of structure for introducing the direct quotations-the use of saying, thinking, or feeling verbs-a similar structure to what is often found in history texts. ${ }^{18}$ Yet in his lesson he did not model or describe this feature to students, and he was not able to name this feature in his reflection on the lesson. Teaching this use of language would have benefitted students both in that specific lesson and beyond.

Both Hunter and Jill designed tasks in which students were asked to recognize that there are multiple viewpoints on the same historical event and to begin to compare these perspectives to think about how perspective impacts belief; it seems that they wanted students to engage in sourcing, contextualizing, and corroborating. However, the language that students would need to use to present and compare these viewpoints was never made

17 Schleppegrell, Achugar, and Oteíza, "The Grammar of History," 87. 18 Ibid. 
explicit to them. Students were not required to use the language of the discipline in meaningful ways. It is also important to note that neither Jill nor Hunter received any guidance on teaching the language of history from their supervising practitioners. The topic Jill's supervising practitioner assigned to her was completely dependent upon using language to make meaning, yet he offered no clear suggestions on how she should teach students to engage with the texts. Hunter's supervising practitioner had told him that she was not comfortable talking about language, indicating that she likely did not integrate language or literacy instruction into her own lessons. Although Hunter's university supervisor asked him to name actual features of persuasive language, it became clear in Hunter's interview that he needed more support to be able to name specific features of language. It seems unrealistic to expect that these preservice history teachers will enact effective instruction in the language of history without both receiving substantial assistance from experienced mentors and observing good examples of language and literacy instruction in history classrooms. It also begs the question: Were they exposed to this language in their undergraduate history courses?

This approach to providing teacher candidates with training in identifying and teaching language in the disciplines was too fragmented to be successful. These findings support Bain's statement about teacher preparation programs in which teacher candidates are expected to gather knowledge and experience from various sources (e.g. history content courses, education courses, and field experiences) and "the person least equipped to do so has the job of coordinating these into a meaningful and useful whole." ${ }^{19}$ The teaching candidates participating in this research wanted their students to "do history," as they had likely learned about in their coursework, yet they did not have enough training in teaching the language and literacy skills necessary to assist students in completing the tasks they assigned. A more integrated

19 Bain, "Using Disciplinary Literacy,” 515. 
study of the history content and disciplinary language, focused directly on the specific language features used in history texts and how to name, teach, and discuss those features with students, would have benefitted these teacher candidates as they planned and implemented lessons in real classroom contexts.

\section{Recommendations}

A complete redesign of the module for preparing secondary teachers to teach disciplinary language features is necessary in order to meet the aforementioned goals. The first, and most important change, would be the creation of separate modules for each content area. The history module should be designed by an expert in language and literacy who is also familiar with the disciplinary demands of history. Working with instructors in the history department to learn more about the content and texts teacher candidates encounter there as well as with the instructors of methods courses to determine what types of language and literacy skills are discussed would be a necessary element of the planning of a history module. One starting point to consider in designing such a training would be the elements of history language from Schleppegrell, Achugar, and Oteiza. ${ }^{20}$ The ways in which students are expected to use and understand these features in reading and writing history texts could be used as the focal point of a module with practice in identifying, naming, and talking about these language features in various types of history texts-primary sources, textbooks, and student writing. Example lesson plans that incorporate teaching of the language features, as well as videos of history teachers teaching this language, would be incorporated to provide models of how language teaching in history can be both planned by teacher candidates and enacted in their field experiences.

While integrating instruction on disciplinary literacy in teacher preparation programs seems like a necessary step, teacher

20 Schleppegrell, Achugar, and Oteíza, “The Grammar of History,” 87. 
educators must also consider the role of in-service history teachers in modeling literacy instruction in their classrooms. The teacher candidates in this study did not report seeing any language being taught in their fieldwork placement classrooms. Teacher candidates need real-life experiences in which the history teachers they observe integrate teaching the language of history into their lessons. With that in mind, the question shifts to include not just what methods best prepare pre-service teachers to teach discipline-specific language, but also how to assist inservice history teachers in bringing language teaching into their classrooms. Just as collaboration among experts in the fields of language and history would be necessary to prepare pre-service teachers to teach the language of history, the same joint endeavor would benefit in-service history teachers. Historians, as experts in the discipline, can provide insight on reading and writing in history and how the language should be used or understood. Language specialists can assist history teachers in identifying specific features to be taught to students and in designing activities in which these features are practiced by students. The spirit of collaboration between disciplinary experts, language teachers, history teacher education programs, and the mentors who work with teacher candidates in their fieldwork experiences, seems to be a crucial element of teacher preparation.

\section{Conclusion}

Bain wrote that "literacy instruction in history classrooms should not be an add-on, but rather is inherently connected to studying the past." ${ }^{\prime 1}$ The way language is used and interpreted in history texts is a reflection of historical thinking. When students do not learn and use the language of history, it is likely that they do not learn the elements of historical thinking reflected in the linguistic choices either. For students to learn the language of history, they must be guided by experts who use and understand

21 Bain, "Using Disciplinary Literacy," 520. 
that language fluently. To ensure that the language of history is taught in every history classroom, all who work to prepare history teachers in university classrooms and fieldwork placements need to share an understanding of the role language plays in doing history and a commitment to teaching that language.

Through quality social studies education, students "are helped systematically to understanding [the world], to take care for it, to think deeply and critically about it." ${ }^{22}$ However, it is not just a focus on the content that builds that foundation for engagement with the world. Students of history need to learn the language necessary to evaluate claims, compare viewpoints, and make judgments about the issues and ideas of the world around them. Learning to "think deeply and critically" 23 does not rely solely on knowledge of the contexts and people involved in the events of the world but relies on close reading of documents and the ability to respond appropriately in both speech and writing. Understanding and using the language of history is an essential component of quality social studies education, education which prepares students to be informed and engaged citizens.

22 Walter C. Parker, "Social Studies Education eC21," in Social Studies Today: Research and Practice, ed. Walter C. Parker (New York: Routledge, 2010), 3 .

23 Ibid. 